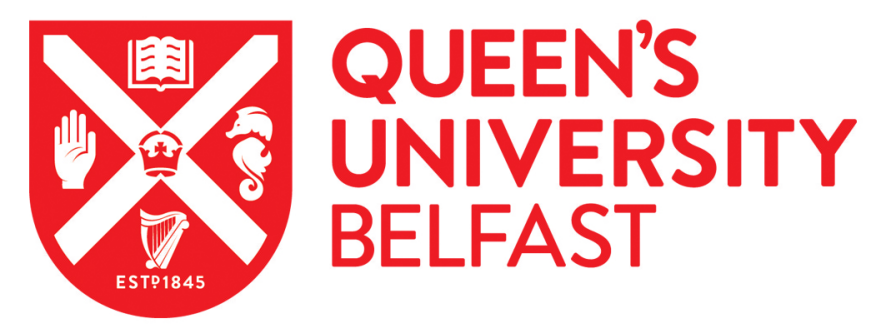

\title{
Outposts of Empire: Scientific Discovery and Colonial Displacement in Gaskell's Wives and Daughters
}

Litvack, L. (2004). Outposts of Empire: Scientific Discovery and Colonial Displacement in Gaskell's Wives and Daughters. The Review of English Studies, 55 (222), 727-758. https://doi.org/10.1093/res/55.222.727

\section{Published in:}

The Review of English Studies

Document Version:

Publisher's PDF, also known as Version of record

Queen's University Belfast - Research Portal:

Link to publication record in Queen's University Belfast Research Portal

\footnotetext{
General rights

Copyright for the publications made accessible via the Queen's University Belfast Research Portal is retained by the author(s) and / or other copyright owners and it is a condition of accessing these publications that users recognise and abide by the legal requirements associated with these rights.
}

Take down policy

The Research Portal is Queen's institutional repository that provides access to Queen's research output. Every effort has been made to ensure that content in the Research Portal does not infringe any person's rights, or applicable UK laws. If you discover content in the Research Portal that you believe breaches copyright or violates any law, please contact openaccess@qub.ac.uk. 


\author{
OUTPOSTS OF EMPIRE: \\ SCIENTIFIC DISCOVERY AND COLONIAL \\ DISPLACEMENT IN GASKELL'S \\ WIVES AND DAUGHTERS
}

\author{
BY LEON LITVACK
}

\begin{abstract}
This article offers a fresh consideration of Elizabeth Gaskell's unfinished Wives and Daughters (1864-6), in terms of what this metropolitan novelist knew about contemporary scientific debates and imperial exploration of Africa, and how her familiarity with these discourses was incorporated into her imaginative work. Her focus for these two related themes is the naturalist Roger Hamley, whose character and exploits are meant to parallel those of the young Charles Darwin. Roger's direct involvement in the historical Geoffroy-Cuvier debate allows Gaskell to offer a sophisticated examination of how discussions about evolutionary biology (about which she learned from personal acquaintances and printed sources) contributed to political and social change in the era of the first Reform Bill. Roger's subsequent journey to Abyssinia to gather specimens allows Gaskell to form a link between science and imperial exploration, which demonstrates how, when carried to its conclusion, the development of classificatory knowledge systems was never innocent; rather, it facilitated colonial exploitation and intervention, which allowed for the 'opening up of Africa'. Gaskell's pronouncements about science in the novel are far more explicit than her brief references to empire; the article ponders why this should be so, and offers some suggestions about how her reliance on imaginative and discursive constructs concerning the 'Dark Continent' may be interpreted as tacit complicity with the imperial project, or at least an interest in its more imaginative aspects.
\end{abstract}

The increasing interest in colonial discourse and post-colonial theory within English studies has forced a re-evaluation of the significance of the British empire to the world of Victorian fiction, and has allowed places like the West Indies, Australia, India, and parts of Africa to become sites for interesting rereadings of canonical nineteenth-century texts. However, insufficient attention has thus far been paid to how Victorian writers acquired information about the outreaches of empire, in order to inform imaginative works set primarily in England. In his book The Mythology of Imperialism Jonah Raskin observes:

I should like to thank the John Rylands University Library, the Manchester Central Library, the Portico Library, the Cambridge University Library, and the Wellcome Library for permission to consult research materials. I should also like to thank Professor Peter J. Bowler, for assistance with specific questions on evolutionary biology, and the organizers of the 'Defining Colonies' conference at NUI Galway, where these ideas were first presented in June 1999. 
In Victorian novels the colonies are usually places to transfer burned out characters, or from which to retrieve characters. . . They are especially convenient for the beginnings, turning points and endings of fiction. The plot began —or flagging interest was revived-when a character returned from abroad, and the action terminated when the characters left for the colonies. For the Victorians existence meant existence in England: it began when they returned to Southampton or Liverpool and it ended when they embarked for Australia, Canada or Nigeria. Going to India was like falling off a cliff. The Englishman coming back to London felt like a fish thrown back into the sea after flopping about on land. ${ }^{1}$

In mid-nineteenth-century metropolitan fiction, colonial spaces are generally peripheral; they function as theatrical 'green rooms' ${ }^{2}$ where characters await their cues to appear in the action, or to which they disappear until recalled for specific purpose or effect. Texts which feature this motif include Dickens's Great Expectations (through Abel Magwitch), Charlotte Brontë's Fane Eyre (through Bertha Mason), ${ }^{3}$ and Wilkie Collins's The Woman in White (through Walter Hartright's absence in Honduras). Often the brief attention given to the colonial experience in these novels is used to show how a character's position is problematized in relation to an 'Other', who might be a convict, a 'Native', an 'Oriental', a 'madwoman in the attic', or some other figure who represents a challenge to ideas about the ascendancy of Englishness and the cultural hegemony to which characters are meant to aspire.

Elizabeth Gaskell's unfinished Wives and Daughters (1864-6), which bears a certain resemblance to George Eliot's Middlemarch (1871-2), ${ }^{4}$ is a text featuring elements which are of interest to critics wishing to examine the social, cultural, and imaginative contexts which permitted-even encouraged-metropolitan writers to use the outreaches of empire to inform and enliven their works. While this novel—subtitled 'An Everyday Story'—largely focuses on the lives of Mr Gibson and his daughter Molly, it also features Roger Hamley, son of the local Tory squire, who has always been overshadowed by his brother Osborne, the heir to Hamley Hall. While Osborne fails at Cambridge, secretly marries a French governess, and dies leaving a new-born child and a disgraced reputation, Roger distinguishes himself as a naturalist while studying at university, becomes Senior Wrangler, and is selected to lead a scientific expedition to East Africa, 'with a view', Gaskell writes, 'to bringing back specimens of the fauna of distant lands, and so forming the nucleus of a museum'. ${ }^{5}$ The importance of a character like Roger

1 The Mythology of Imperialism (New York, 1971), 17-18.

2 L. Litvack, 'Dickens, Australia and Magwitch Part I: The Colonial Context', Dickensian, 95 (1999), 25.

3 Fane Eyre also features the advent, from Madeira, of John Eyre's wealth, which allows Jane to attain independence.

4 See B. Hardy, 'Mrs Gaskell and George Eliot', in A. Pollard (ed.), The Victorians (London, 1970), 169-94.

5 Wives and Daughters, ed. F. G. Smith (Harmondsworth, 1986), 405 (hereafter WD). 
is confirmed by Chapple, who notes that in the high noon of Victorian optimism scientists are as suitable as captains of industry to play leading roles in the most popular literary form of the age'. ${ }^{6}$

While Roger (whose original surname was to have been Newton) serves as the embodiment of both scientific and imperial interest in the text, these two fields of endeavour are not explored with the same level of diligence by Gaskell. In May 1864, while she was planning Wives and Daughters, she wrote to George Smith, publisher of the Cornhill Magazine, with an outline of her work; she intimated that Roger 'works out for himself a certain name in Natural Science' and is 'tempted by a large offer to go round the world (like Charles Darwin) as a naturalist'. ${ }^{7}$ In many ways Roger is like the young Darwin (1809-82): kindly, rational, practical, a devoted brother, a submissive son, and one endowed with great powers of observation. ${ }^{8}$ Darwin was a distant cousin of Gaskell's, and when, in 1851, she had the chance to invite him for dinner, she clearly looked forward to the occasion. ${ }^{9}$ They were never close; but Darwin did own and read Gaskell's novels: he considered Ruth (1853) 'quite charming', and viewed North and South (1854-5) favourably. ${ }^{10}$ Gaskell was clearly aware of scientific developments through other family connections, including her cousin Henry Holland (1788-1873, who was at the centre of radical and intellectual circles

\section{J. A. V. Chapple, Science and Literature in the Nineteenth Century (Houndmills, 1986), 7.}

7 The Letters of Mrs Gaskell, ed. J. A. V. Chapple and A. Pollard (Manchester, 1966), 732 (hereafter Letters). The letter is dated 3 May 1864.

8 Additional points of comparison between Darwin and Roger are provided in M. Debrabant, 'Birds, Bees and Darwinian Survival Strategies in Wives and Daughters', Gaskell Society fournal, 16 (2002), 16.

9 See Letters, 157, where she writes to Eliza Fox to say that she has not seen Darwin since before he had 'been round the world'- presumably on the voyage of the Beagle (1831-6). Darwin is also briefly discussed in A. Unsworth, 'Some Social Themes in Wives and Daughters (1): Education, Science and Heredity', Gaskell Society Fournal, 4 (1990), 47-8.

10 On Ruth see Darwin's letter to Joseph Dalton Hooker, dated 10 Oct. 1853, in The Correspondence of Charles Darmin, ed. F. Burkhardt and S. Smith, vol. v: 1851-1855 (Cambridge, 1989), 161. Darwin lent his copies of Mary Barton and North and South to Hooker, who wrote to his friend in August 1867 as follows: 'I return, by the Train to Bromley, Mary Barton \& Vol. II of North \& South-The whole of the vraisemblable of the latter falls before the Darwinian Gospel—how could such imbecile parents have such a child as Margaret? Also the denouement is too abrupt, \& I have no sympathy with the Hero. As to Mary Barton it is the most horrible story I ever read-I got through the first $\frac{1 \mathrm{~d}}{3}$ of the book of deaths of all classes \& ages of starvation, fever, \& consumption spiced and garnished with Paralysis \& blindnesswhen poor Esther came on the scene \& floored me-I took therefore a sip or two of the last chapter, \& being somewhat revived thereby, I managed to struggle through the rest. Esther is the blunder of the book - there was no occasion to run her hopeless hopeless [sic] misery through the whole story, \& thus leave a most painful impression of the whole book-a regular poisoning of the tale- It is tremendously unnatural \& sensational in plot \& matter but most powerful, \& I suppose extremely well written-At least I could always reread bits with pleasure. The life of the Manchester work people, is I suppose portrayed to the life.' Darwin replied on 2 Sept. 1867, to say that he believed Dalton did not 'do justice' to Mary Barton. I am indebted to Anna-Kateria Meyer and the Darwin Letters project at Cambridge University for permission to quote from these two yet unpublished letters. The originals may be found in the Darwin papers, Cambridge University Library, DAR 102: 174-5 and DAR 94: 33-4. 
in the $1820 \mathrm{~s}$ and $1830 \mathrm{~s}),{ }^{11}$ and her husband William Gaskell, who followed scientific innovation closely, taught natural history to his family, and in 1840 became a member of the Manchester Literary and Philosophical Society. ${ }^{12}$ The 'Lit. and Phil.', whose special interests were science, the arts, and current social issues, was famous throughout England, and counted among its members the chemist John Dalton (1766-1844), who held the presidency until his death. ${ }^{13}$ The Gaskells knew a good number of scientific people, ${ }^{14}$ including the aristocratic amateur Francis Egerton, first earl of Ellesmere (1800-57, patron of Manchester science); her close friend Benjamin Brodie (1817-80, professor of chemistry at Oxford); the industrialist and analytical chemist Edward Schunck (1820-1903); the engineers William Fairbairn (1789-1874) and James Nasmyth (1802-90); the Unitarian physiologist William Benjamin Carpenter (1813-85); the physicist James Prescott Joule (1818-89) $;^{15}$ William Whewell (1794-1866, a dominant figure in the philosophy of science) $;^{16}$ Jane Marcet (1769-1858); and Mary Somerville (17801872). ${ }^{17}$

In Wives and Daughters Gaskell endows three of the central male characters with scientific interest. Mr Gibson, a doctor by profession, ${ }^{18}$ is fascinated by

11 Holland, a doctor by profession, was admitted to the Royal Society in 1816 . He wrote a number of important scientific articles for the Edinburgh Reviem and Quarterly Reviem (see below), and became physician-in-ordinary to Queen Victoria in 1852. See Holland's Recollections of Past Life (London, 1872).

12 William Gaskell eventually became chairman of the Lit. and Phil.

13 In an attempt to demonstrate how Knutsford, where Gaskell spent her early years, was a place open to new ideas, Uglow recounts how in 1814 Dalton gave a course of scientific lectures there: Elizabeth Gaskell, A Habit of Stories (London, 1993), 30.

14 See ibid. 560. Uglow's list of scientific personalities is recalled by L. Henson in 'The "Condition-of-England" Debate and the "Natural History of Man": An Important Scientific Context for the Social-Problem Fiction of Elizabeth Gaskell', Gaskell Society Fournal, 16 (2002), 30. For a general assessment of 19th-century scientific activities in the city see R. H. Kargon, Sciences in Victorian Manchester: Enterprise and Expertise (Manchester, 1977).

15 Joule was a pupil of James Dalton. For a letter to William Gaskell from Joule see 'Letters to Elizabeth Cleghorn Gaskell and William Gaskell', John Rylands University Library of Manchester, MS 730, letter no. 53.

16 See 'Letters to Elizabeth Cleghorn Gaskell and William Gaskell', John Rylands University Library of Manchester, MS 731, letter no. 107. Whewell was the Master of Trinity College Cambridge; it was through his efforts that the Natural Sciences tripos was established at the university in 1848; for the study of natural history at Cambridge see WD 106.

17 For the letters of Marcet and Somerville see 'Elizabeth Gaskell: Miscellaneous Letters', John Rylands Library, MS 732, letter no. 103; 'Letters to Elizabeth Cleghorn Gaskell and William Gaskell', John Rylands Library, MS 731, letter no. 94. Marcet published two Conversations, written specially for women: Natural Philosophy and Vegetable Physiology; Somerville, who was a pioneer in popularizing science, published On the Connexion of the Physical Sciences (1834), a work which dealt with astronomy, meteorology, theory of tides, botanical geography, sound, light, heat, electricity, and magnetism.

18 Sharps observes that Mr Gibson was inspired by Gaskell's recollections of her uncle, Dr Peter Holland (1766-1855), the Knutsford surgeon whom she accompanied on his rounds. J. G. Sharps, Mrs. Gaskell's Observation and Invention: A Study of her Non-Biographic Works (Fontwell, 1970), 483. 
comparative osteology, but demonstrates limited expertise. According to Gaskell his knowledge is dwarfed by that of Lord Hollingford (WD 134), who not only writes papers for learned journals, but even has his own laboratory; it is he who secures sponsorship for Roger's first expedition. While Hollingford has clearly progressed beyond enquiries into natural theology ${ }^{19}$-a predominant strand in early nineteenth-century English interest in scientific matters-he is still an amateur, and stands for a general public interest in scientific matters. Roger, on the other hand, represents a new generation of scientific men in England, who wish to pursue their discipline on a professional level.

There is some discussion in the text about the theories of comparative anatomy which were in circulation in the 1820s (when the novel is set), and it is here that Gaskell demonstrates a high degree of perception. Molly and Roger discuss François Huber's Nouvelles observations sur les abeilles, or Nem Observations on Bees (1792; see WD 204), a work which discusses, among other things, experiments with bees' cells-a subject that fascinated Darwin. ${ }^{20}$ While such intertextual references have been noted by, for example, Debrabant $^{21}$ and Henson, ${ }^{22}$ these critics do not treat a more important scientific issue: the Geoffroy-Cuvier debate, which Gaskell uses as the basis for an insightful assessment of social and political trends and sympathies in Wives and Daughters. Molly reports that Roger reads to her portions of Le Règne Animal (WD 340), a work published in 1817 by Georges Chrétien Dagobert, Baron Cuvier (1769-1832), who almost single-handedly founded vertebrate palaeontology as a scientific discipline and created the comparative method of organismal biology. He contributed an immense amount of research in vertebrate and invertebrate zoology and palaeontology, and wrote and lectured on the history of science. It was Cuvier who firmly established the fact of the extinction of past life forms; he also held the distinction of serving in three different forms of French government: revolutionary, Napoleonic, and

19 In essence, natural theology attempted to reconcile recent discoveries with support for belief in a Creator and Designer. For example the geologist and palaeontologist William Buckland (1784-1856) attempted to reconcile Genesis and geology; to this end he published Reliquae Deluvianae; or, Observations on the Organic Remains Contained in Caves, Fissures, and Diluvial Gravel, and on Other Geological Phenomena, Attesting the Action of an Universal Deluge (1834). He also wrote the Bridgewater Treatise for 1837, entitled Geology and Mineralogy Considered with Reference to Natural Theology: this was a comprehensive survey of the fossil record, each species being described as an example of divine workmanship, perfectly adapted to the lifestyle it employed to gain a livelihood in the prevailing environment of its time. Francis Henry Egerton, eighth earl of Bridgewater (1756-1829), who endowed this prize for the best work on 'The Goodness of God as manifested in the Creation', is mentioned in Gaskell's novel as a parallel to 'that rich eccentric Mr Crichton', who 'left a sum of money in the hands of trustees . . . to send out a man with a thousand fine qualifications, to make a scientific voyage' (WD 405).

20 On the hive bee's cell-making instinct see On the Origin of Species by Means of Natural Selection, or the Preservation of Favoured Races in the Struggle for Life, ed. J. W. Burrow (Harmondsworth, 1985), 247-56.

21 'Birds, Bees, and Darwinian Survival Strategies', 16.

22 'The "Condition-of-England" Debate', 45. 
monarchist. An article of Cuvier's is given an adverse review by Roger, who is said to possess 'a most unusual amount of knowledge on the subject' (WD 339); he presumably objects to Cuvier's statements concerning the nature of species and their fixity. His father Squire Hamley - a Tory landowner who has lived through the Napoleonic Wars - objects to Cuvier's stance simply because the anatomist is French; he tells Roger: 'We had to beat 'em, and we did it at Waterloo; but I'd not demean myself by answering any of their lies, if I was you' (WD 393). Cuvier did not believe in organic evolution, for any change in an organism's anatomy would, he reasoned, have rendered it unable to survive. He studied the mummified cats and birds that had been brought back from Napoleon's invasion of Egypt, and showed that they were no different from their living counterparts; he used this to support his claim that life forms did not evolve over time, but instead could be broken down into discrete divisions. ${ }^{23}$ Organisms were, he held, functional wholes; any change in one part would destroy the delicate balance.

Standing in opposition to Cuvier in terms of historical scientific debates was the zoologist and comparative anatomist Étienne Geoffroy St Hilaire (17721844; Figure 1), who risked his life to save some of his teachers and colleagues during the Reign of Terror, and, after inviting the young Georges Cuvier to Paris, collaborated with him on several research projects. Geoffroy accompanied Napoleon's invasion of Egypt in 1798, and brought back many of the animal specimens which Cuvier would later study and cite as proof that evolution had not occurred. Geoffroy developed the concept of 'transcendental anatomy', which was based on his ideas about 'unity of composition' for all animals. He concluded that not only were all vertebrates built to the same blueprint, but all animal life-including insects, molluscs, and human beings - could be strung into a continuous, related series, rather than broken into Cuvier's discrete divisions. It was this idea that enhanced the prospect of evolution. ${ }^{24}$

Roger Hamley is depicted by Gaskell as concurring with the views of 'Geoffroi St. H—' (WD 343), from whom he receives an invitation to dinner, because the Frenchman wishes 'to meet the author of the paper which had already attracted the attention of the French comparative anatomists' (WD 343). ${ }^{25}$ Osborne, who has more sympathy with the French than his father,

23 Cuvier classified animals into four 'branches', or embranchements: Vertebrata, Articulata (arthropods and segmented worms), Mollusca (which at the time meant all other soft, bilaterally symmetrical invertebrates), and Radiata (cnidarians and echinoderms). For Cuvier, these embranchements were fundamentally different from each other and could not be connected by any evolutionary transformation.

24 See especially his book Philosophie anatomique: des organes respiratoires sous le rapport de la détermination et de l'identité des leurs pièces osseuses (Paris, 1818), in which he posits that all vertebrates are modifications of a single archetype or form.

25 In the manuscript Gaskell had originally written that Geoffroy was 'staying' at the Towers; this was crossed out, and replaced with 'expected to pay a visit': autograph manuscript of Wives and Daughters, John Rylands Library, English MS no. 877; the leaves are unnumbered. 


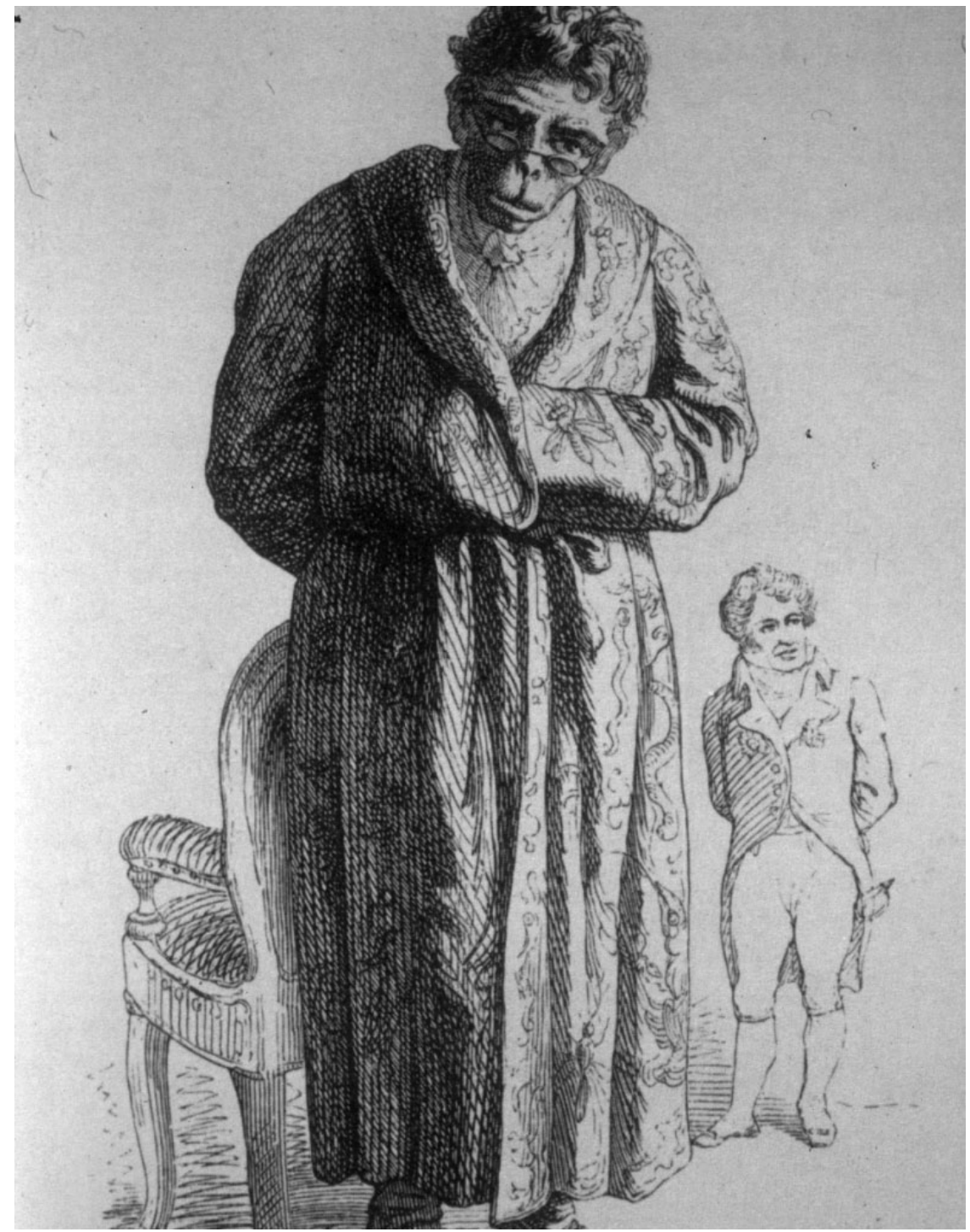

Figure 1. The comparative anatomist Étienne Geoffroy St Hilaire, depicted as an orangutan, with a diminutive Baron Georges Cuvier in the background. From Pierre-Jules Hetzel, Scènes de la vie privée et publique des animaux (Paris, 1842), 201.

observes that 'Roger is making himself known for what he is, a first-rate fellow ... and he is getting himself a name; he's been writing about these new French theories and discoveries, and this foreign savant very naturally wants to make his acquaintance' (WD 344). As Roger's character is inspired by the career of the young Darwin, it might come as no surprise that after Jean Baptiste Lamarck (1744-1829), the next important figure to be mentioned in the 
preface to On the Origin of Species (1859) is Geoffroy. Darwin remarks on the coincidence which occurred in England, Germany, and France in the years 1794-5, when Erasmus Darwin, Goethe, and Geoffroy 'came to the same conclusion on the origin of species'; he continues:

Geoffroy Saint-Hilaire . . suspected, as early as 1795 , that what we call species are various degenerations of the same type. It was not until 1828 that he published his conviction that the same forms have not been perpetuated since the origin of all things. Geoffroy seems to have relied chiefly on the conditions of life, or the 'monde ambiant' as the cause of change. He was cautious in drawing conclusions, and did not believe that existing species are now undergoing modification; and, as his son adds, 'C'est donc un problème à réserver entièrement à l'avenir, supposé même que l'avenir doive avoir prise sur lui. ${ }^{26}$

Geoffroy spent much time drawing up rules for deciding when structures in two different organisms were variants of the same type-in modern terminology, when they were homologous. His criterion was connections between parts: structures in different organisms were the same if their parts were connected to each other in the same pattern. Later in On the Origin of Species Darwin wrote:

What can be more curious than that the hand of a man, formed for grasping, that of a mole for digging, the leg of the horse, the paddle of the porpoise, and the wing of the bat, should all be constructed on the same pattern, and should include the same bones, in the same relative positions? Geoffroy St. Hilaire has insisted strongly on the high importance of relative connexion in homologous organs: the parts may change to almost any extent in form and size, and yet they always remain connected together in the same order. ${ }^{27}$

Geoffroy was among the first to grasp an extremely important concept. For Darwin and for evolutionary biologists after him, defining and identifying homologous structures became both an important source of support for evolution and an important tool for identifying evolutionary relationships. In On the Origin of Species Darwin also mentions Geoffroy's son, Isidore Geoffroy St Hilaire, who in 1844 succeeded his father as professor of zoology at the Muséum d'Histoire Naturelle in Paris, and became a prominent zoologist and embryologist in his own right. Gaskell had met Isidore when she was in France in February 1855; before the event she confided to her daughter, 'I'm afraid we shall have to talk zoologically—\& be kissed. ${ }^{28}$

When the terms of the Geoffroy-Cuvier debate are applied to the various social situations and political institutions discussed in Wives and Daughters, it is clear that Gaskell is keenly aware of the sensitivities involved, and, by setting

26 Darwin, preface to On the Origin of Species, 55.

27 Ibid. 415.

28 Letters, 332. Debrabant confuses Geoffroy perre et fils, wrongly implying that Gaskell met the father in Paris in 1855 ('Birds, Bees, and Darwinian Survival Strategies', 15). 
her novel in the period just before the first Reform Bill, she invites her readers to compare past with present. ${ }^{29}$ She models the fictional Hollingford (meant to be in the Midlands) on the area around Knutsford in Cheshire, where she was raised by her aunt. ${ }^{30}$ When the novel opens Gaskell intimates that 'a very pretty amount of feudal feeling still lingered' about the place (WD 36), and that the townspeople 'would have stood still in amazement, and with a horrid memory ${ }^{31}$ of the French sansculottes who were the bugbears of their youth', had any inhabitant of Hollingford 'ventured to set his will or opinions' against those of the family of Lord Cumnor. Anti-French feeling is, as noted above, evoked particularly by the Tory Squire Hamley, who thinks of the Cumnors as 'Whig rascals' (WD 377), and is suspicious of Roger's invitation to meet Geoffroy. He tells his sons:

You young men think you know everything. I tell you it's a palpable Whig trick. And what business has Roger ... to go currying favour with the French? In my day we were content to hate 'em and to lick 'em.... What business had you to go writing about the French, Roger? I should have thought you were too sensible to take any notice of their fancies and theories. (WD 344)

Despite the Squire's histrionic Francophobic displays, Gaskell makes certain that she treats him throughout with tenderness and understanding-particularly in scenes associated with death. This impression is conveyed, for example, in chapter 22 ('The Old Squire's Troubles'), which is set after the death of Mrs Hamley. Here Gaskell takes the opportunity to develop the contrast between Roger and Osborne, and to catalogue various changes at Hamley Hall: the decline of equestrian pursuits, including hunting, and the disposal of Mrs Hamley's old coach; the pathos is heightened through the narrator's recording an interchange with an old horse, in which the Squire tells the animal 'of the change of times since both were in their prime' (WD 289). In chapter 30 ('Old Ways and New Ways') the Squire visits the dying gamekeeper, Old Silas, who has asked to see his master out of a sense of 'feudal loyalty', which offers 'comfort' in his final hours (WD 377). Also, after the death of Osborne in chapter 52, his wife Aimée-a French Catholic nursery governess, and symbol of all those qualities of class, nationality, and religion that the Squire detests-arrives at Hamley Hall (WD 626). Upon seeing his grandson, named Roger, he begins to soften, and tries to convince himself that Aimée is 'not like a Frenchwoman', and does not 'look like a servant' (WD 629). The seeds of change have taken root: the advent of the Victorian era will bring with it the demise of many long-cherished certainties and traditions; yet

29 The main action runs from 1827 to 1830 , when Gaskell herself was a young daughter.

30 At many points in the early part of the manuscript for chapter 1 Gaskell had originally written 'Chesterford'; this was later crossed out, and replaced by 'Hollingford': autograph manuscript of Wives and Daughters.

31 The manuscript originally had 'dread', which is crossed out in favour of 'memory': autograph manuscript of Wives and Daughters. 
Gaskell is careful to mark their passing with great feeling and a certain amount of sorrow. ${ }^{32}$

The leading personification of change is, of course Roger. Throughout the novel Gaskell endows him with those qualities which are needed to survive the rigours and challenges of modern life, and thus avoid extinction. He is 'steady and sober', 'tall', and 'powerfully made'; he gives the impression 'of strength more than elegance', and maintains a serious attitude, often resisting the impulse to laugh $(W D 98,119)$. He is a character whose traits are worthy of inclusion in a work like Samuel Smiles's Self-Help (1859):

He looked forward to an active life; in what direction he had not yet determined. $\mathrm{He}$ knew what were his talents and his tastes; and did not wish the former to lie buried, nor the latter, which he regarded as gifts, fitting him for some peculiar work, to be disregarded or thwarted. He rather liked awaiting an object, secure in his own energy to force his way to it, when he once saw it clearly. He reserved enough of money for his own personal needs, which were small, and for the ready furtherance of any project he might see fit to undertake. (WD 391)

Roger's eventual companion, with whom he shares the intellectual, moral, and familial challenges of the Victorian age, is Molly Gibson. Their relationship grows organically: he introduces her progressively into his world, playing the role of 'Mentor' to her 'Telemachus' ( $W D$ 172). Initially he invites her to look into the microscope, cherishing 'her first little morsel of curiosity' (WD 155); he then encourages her to observe the natural world around her (WD 184), and informs her about 'late discoveries in natural history' (WD 249). Despite her father's initial desire that she should not have an education beyond reading, writing, sewing, and sums (WD 65), her love of books, encouraged by Roger, extends to the point where she - alone among female characters in the textcarries on a conversation with Lord Hollingford about science, including the work of Cuvier, thus evincing 'so much intelligence', and demonstrating that she possessed a 'mind so well prepared for the reception of information' (WD 339). Molly has clearly come a long way since her childhood, when she confessed 'I don't understand French. I'm only Molly Gibson' (WD 53). Her edification in the course of the text is emblematic of the opening up of certain male-dominated realms of knowledge - not with the aim of making her a radical icon, but rather suggesting a wider range of possibilities for women to understand and contribute to key debates of the day. Thus, like Roger, Molly displays a preparedness to deal with the challenges that the Victorian age would bring.

Despite Roger's many admirable traits, he-like Dickens's David Copperfield-must learn to discipline his heart in the course of the narrative; by tracing this process Gaskell transforms Roger from an emblem into a living,

32 Debrabant believes that the Hamleys are a 'a race rooted in archaic, elitist customs and running the risk of extinction' ('Birds, Bees, and Darwinian Survival Strategies', 17); yet Gaskell's presentation is not as pejorative as this observation would suggest. 
breathing character. The appeal of the lovely Cynthia (WD 278) throws him 'off his balance', making him seem 'like an unreasoning child' (WD 391) in his pursuit of her. After he proposes to her (WD 419) he departs on his expedition; presumably the trials he undergoes not only hone his survival instincts, but also allow diligence, prudence, self-denial, and surety of purpose to act upon his sensibilities. For exigency of plot, Roger's absence allows for Cynthia's involvement with Preston to reach its climax, in chapters 43-5. She, however, undergoes little development during this interval: her reliance on Molly and Lady Harriet to resolve the Preston affair reveals her cowardice, as does her breaking off the betrothal to Roger by correspondence, rather than face to face. She acknowledges: 'I couldn't bear to have to tell him I'm sorry, and stand before him like a chidden child to be admonished and forgiven' (WD 601). One final point confirms the unsuitability of Cynthia as a companion for Roger: in comparing her taste in books with Molly's, Gaskell notes that Cynthia prefers her Boulogne schoolbook, Le Siècle de Louis XIV, over Cuvier's Le Règne Animal (WD 340). The latter is recommended to Cynthia by her acquisitive, ruthless mother, and it is ironic that Mrs Gibson, who possesses strong inclinations towards survival, recommends a book by a man whose greatest contribution to biology was the establishment of extinction as a fact.

Science, when considered more generally as a presence in the text, is the precursor to a new era, in which barriers of class, intellect, and gender are being interrogated; it is interesting to observe Lord Hollingford (a Whig with affinity for the French), Mr Gibson (a member of the medical profession), and Roger (the scientific son of a Francophobe Tory landowner) all coming together to discuss their mutual passion. When the formation of this triumvirate is placed alongside Gaskell's Unitarian background and her familiarity with those who moved in radical circles ${ }^{33}$ it appears that the situation in Wives and Daughters is meant to echo the radical movement both within and without the realm of science, that was prepared to exploit materialism - that is, the evolutionary belief that human beings were part of the animal kingdom-as part of a campaign against the establishment. Geoffroy was a key figure in this debate, because, as a transformationist, he argued that new variants on the archetypal pattern might be produced by natural means. ${ }^{34}$ Radical publications, which campaigned against the privileged position of the Church and the aristocracy, used the scientific arguments of figures such as Geoffroy to support their claim that humans are nothing more than highly developed animals; in this way they

33 Gaskell's contact with radicalism was facilitated not only her cousin Henry Holland, but also by William and Mary Howitt, who helped Gaskell to get her material into print in 1847-8. See Uglow, Elizabeth Gaskell, 17, 170.

34 See A. Desmond, The Politics of Evolution: Morphology, Medicine, and Reform in Radical London (Chicago, 1989). This penetrating study analyses the work of Geoffroy as a means to understanding radical science-particularly as it developed in the medical schools of London and Edinburgh in the late 1820 s, and especially in the 1830 s. On the different approaches which the English and French took to science see D. Knight, 'Rivalry with the French', in The Age of Science: The Scientific World-viem in the Nineteenth Century (Oxford, 1986), 11-31. 
undermined the conviction that the soul was capable of appreciating divinely revealed truths - a belief which always seemed to imply support for the existing social hierarchy. ${ }^{35}$ Though radicalism is heavily codified in Wives and Daughters, it is clear from Roger's intellectual association with Geoffroy that Gaskell's ideas concerning the potential for change in Hollingford society are linked to scientific and political forces prominent in early nineteenth-century England.

It is difficult to discover precisely where or when Gaskell acquired the knowledge necessary to write about the scientific developments in Wives and Daughters in such a sophisticated way. Important clues are, however, provided by what may be discerned of her reading habits. She had ready access to books and journals through the acquisitions made by Manchester's Portico Library, of which William Gaskell was chairman from 1849 until his death in 1884. The institution was founded in 1806; by the time the Gaskells came to the city it had established itself as a major subscription library for the professional middle classes. Because women were excluded from becoming members Elizabeth could not borrow books in her own right, ${ }^{36}$ instead she relied on her husband's association with the library: either he borrowed books for her, or she took books out herself in William's name. ${ }^{37}$ It is possible to follow the daily borrowings by the members (who are called 'proprietors') by examining the issue books, which the library has preserved. ${ }^{38}$ During the period $1850-9$, borrowings in William's name totalled over 700 items. These loans included items from all three of the institution's original subject classifications-'Polite Literature', 'Fine Arts', and 'Voyages \& Travels' ${ }^{39}$ - and included contemporary fiction and poetry, educational works, historical and social studies, biography, and travelogues. ${ }^{40}$ The Portico's own collection was supplemented by volumes requested from the two major circulating libraries, Mudie's and W. H. Smith; these borrowings were also recorded in the issue books. ${ }^{41}$

While the books borrowed in the 1850s do not include scientific works, it is

35 See P. J. Bowler, Charles Darmin: The Man and his Influence (Cambridge, 1996), 20. Lamarck's ideas were also employed by radicals in this way. Bowler notes that they 'may not have understood the details of Lamarck's arguments, but they knew that his theory had implications that were directly relevant to their case'.

36 See Letters, 567, where she complains to George Smith that 'with a struggle and a fight I can see all the Quarterlies [that is, the Quarterly Reviem] 3 months after they are published; till then they lie on the Portico table, for gentlemen to see'.

37 For a consideration of possible borrowings made on Elizabeth's behalf see S. Foster, " "We sit and read and dream our time away": Elizabeth Gaskell and the Portico Library', Gaskell Society Fournal, 14 (2000), 15. Foster also notes that the Winkworth sisters were Portico readers (p. 14).

38 Issue books exist from 1850 onward. For a general overview see B. Brill and A. Shelston, 'Manchester: "A Behindhand Place for Books": The Gaskells and the Portico Library', Gaskell Society Fournal, 5 (1991), 27-36.

39 These headings are still visible on the Portico's walls today.

40 See Foster's 'Gaskell and the Portico Library', 15-21, as well as her later work, Elizabeth Gaskell: A Literary Life (Houndmills, 2002), 74-7.

41 The library paid an annual subscription of $\oint_{\mathrm{s}} 15.15 \mathrm{~s}$. $0 \mathrm{~d}$. in the 1860 s to each circulating library; see minutes of the Library Committee meetings of 5 Feb. 1861 and 7 Feb. 1865. 
possible that Gaskell remained informed about developments through William's regular borrowing of periodicals, including The Westminster Reviem, The Quarterly Reviem, and The Edinburgh Reviem. The Westminster, which originated among the Philosophic Radicals (including Jeremy Bentham) in the $1820 \mathrm{~s}$, stood for moral, political, religious, and social progress. ${ }^{42}$ It offered extensive coverage of scientific matters by scholars of distinction, including T. H. Huxley (1825-95) and John Tyndall (1820-93). Indeed the journal carried a separate scientific review section; in the first of these, in January 1854, Huxley discusses scientific method, in the context of George Henry Lewes's book on Comte's positivism, together with chemistry, physics, geology, biology, mental physiology, and pathology. ${ }^{43}$ In other reviews Huxley treated natural history; for example, in April 1854 he considered Isidore Geoffroy St Hilaire's Histoire Naturelle Générale des Règnes Organiques. The discussion is informed by the work of the elder Geoffroy and Cuvier, and points out Isidore's strengths, as well as his weaknesses. ${ }^{44}$ Huxley continued to review regularly_-particularly in the field of natural history-until 1856 . He returned in 1860, to write a review of Darwin's Origin of Species. In this latter contribution he asserted that it was not possible to 'pick holes of any great importance' in the argument, and concluded:

We do not hesitate to assert that it is as superior to any preceding or contemporary hypothesis, in the extent of observational and experimental basis on which it rests, in its rigorously scientific method, and in its power of explaining biological phenomena, as was the hypothesis of Copernicus to the speculations of Ptolemy . . . we owe the author of 'The Origin of Species' an immense debt of gratitude. ${ }^{45}$

If Gaskell had read these pieces in the Westminster-either in the Portico copy, or in an issue borrowed from friends ${ }^{46}$ - she would not only have become acquainted with the major scientific figures who were later to inform Wives and Daughters, but would also have encountered a highly informed, progressivist position on evolutionary biology.

The Quarterly Reviem, which is mentioned twice in the novel (WD 300, 699), discussed natural history more hesitatingly than did the Westminster, and refused to follow the implications for human origins to their conclusion. In 1849 it had published Henry Holland's 'Natural History of Man', a review of works on geology, ethnology, natural history, and language classification, designed to demonstrate the allied advances in language and the human species. While citing evidence from the likes of Lyell, Lamarck, and Cuvier,

42 See the introduction to The Westminster Reviem in The Wellesley Index to Victorian Periodicals, vol. iii (Toronto, 1979), 528-53.

43 [T. H. Huxley], 'Science', Westminster Reviem, 61 (1854), 254-70.

44 [T.H. Huxley], 'Science', ibid. 580-95.

45 [T. H. Huxley], 'Darwin on the Origin of Species', Westminster Reviem, 73 (1860), 568, 569.

46 See Letters, 239, where Gaskell notes that William had borrowed an issue of the Westminster for her from friends. 
and concluding that 'there is no subject of science of deeper interest than ... the natural history and original condition of man', Gaskell's cousin ultimately adopts a creationist standpoint in this Tory publication. ${ }^{47}$ The Quarterly also praised the work of the British comparative anatomist Richard Owen (180492), who wrote for the journal, ${ }^{48}$ coined the term 'dinosauria', and synthesized French anatomical work, especially from Cuvier and Geoffroy. Taking homology (another concept he formulated) to its conclusion, Owen reasoned that there must exist a common structural plan or 'archetype' for all vertebrates; however, instead of proving this idea through animal ancestry, he posited that the archetype represented an idea in the divine mind, which also anticipated all forms of modification. The Quarterly praised Owen's work-especially his early efforts, in an extended review of fifteen volumes, in which the palaeontologist is referred to as the 'Cuvier of England' ${ }^{49}$ In the late 1850s the Quarterly continued to support Owen, and to oppose Darwin; when the Origin of Species was published, the journal responded with a review by the bishop of Oxford, Samuel Wilberforce (1805-73), himself an amateur naturalist. He found fault with Darwin's argument, and concluded: 'That Mr. Darwin should have wandered from this broad highway of nature's works into the jungle of fanciful assumption is no small evil. ${ }^{50}$

Owen's own opposition to Darwin's Origin was made public in the Edinburgh Reviem, a publication which is perused by $\mathrm{Mr}$ Gibson in Wives and Daughters, and by Sir Charles Morton, who reads aloud from it to Molly, Lady Cumnor, and Lady Harriet (WD 451, 671). ${ }^{51}$ The notorious review attempted to undercut Darwin, by calling his hypotheses 'conjectural' and championing Owen's own position: that there was a 'constantly operating secondary creational law' governing the 'continuous operation of the ordained becoming of living things'. ${ }^{52}$ Concerns were also raised in other

47 [H. Holland], 'Natural History of Man', Quarterly Reviem, 86 (1849), 39. Holland's review treats James C. Pritchard's Researches into the Physical History of Mankind (1836-47) and The Natural History of Man (1843), C. Hamilton Smith's The Natural History of the Human Species (1848), C. C. J. Bunsen's On the Results of Recent Egyptian Researches, in Reference to Asiatic and African Ethnology and the Classification of Languages (1847), and Charles Lyell's Elements of Geology. Holland's treatment of Pritchard is discussed in some detail, particularly in relation to anthropology and the social problem novel, in Henson, 'The "Condition-of-England" Debate', $32-8$.

48 See e.g. [R. Owen], 'Lyell on Life and its Successful Development', Quarterly Reviem, 89 (1851), 412-51.

49 [W. J. Broderip], 'Progress of Comparative Anatomy', Quarterly Reviem, 90 (1852), 363. For further information on Owen see N. A. Rupke, Richard Omen: Victorian Naturalist (New Haven, 1994).

50 [S. Wilberforce], 'Darwin's Origin of Species', Quarterly Reviem, 108 (1860), 263.

51 The presence of the Edinburgh Reviem at the Towers is another confirmation of the Cumnors' Whig credentials.

52 [R. Owen], 'Darwin, On the Origin of Species', Edinburgh Reviem, 111 (1860), 503, 500. It should be noted that in the late 1830s Owen had used the fossil vertebrates which Darwin had brought back from South America on the Beagle to support his own hypotheses. 
articles, such as the review of Lyell's Geological Evidences of the Antiquity of Man, by the glaciologist J. D. Forbes, who noted the agitation in the public mind concerning the discovery of human fossils: 'The consciousness of a prevailing current of thought on this subject, never exactly rising to the surface, leaves the reader with that uncomfortable amount of scepticism which loosens one set of ideas without giving a firm hold to any by which they can be replaced. ${ }^{53}$

This brief survey of periodical pronouncements provides some idea of the cross-section of scientific opinions - some of them passionately expressed-to which Gaskell was exposed in the years leading up to Wives and Daughters. She was clearly aware of the different hypotheses proposed by Geoffroy and Cuvier, as well as their development by Owen, Darwin, Huxley, and others. During the period of the novel's composition, William Gaskell continued to borrow journals, including the Westminster, Quarterly, and Edinburgh, along with Blackwood's Edinburgh Magazine, Fraser's, the National Reviem, the Fortnightly Review, the British Quarterly Reviem, and Revue des Deux Mondes; by then, however, the major figures had made their positions clear, and so Gaskell was able to draw on a recognizable framework of scientific debate spanning the previous thirty years. Among the books William borrowed from the Portico in 1864-5, the only one which might be relevant to the depiction of science in Wives and Daughters is Gilbert White's Natural History of Selbourne, ${ }^{54}$ obtained on 14 July 1865; first published in 1789 , this book encouraged readers to observe the rhythm of the seasons, and taught them to record nature's trifling phenomena. Darwin had pored over White's book as a teenager, and read it again in February 1843, in the edition published by his friend, the Revd Leonard Jenyns. ${ }^{55}$ It might have influenced Gaskell's presentation of Roger's powers of observation, which are in evidence when he is out collecting specimens:

He had gone about twenty yards on the small wood-path at right angles to the terrace, when, looking among the grass and wild plants under the trees, he spied out one which was rare, one which he had been long wishing to find in flower, and saw it at last, with those bright keen eyes of his. Down went his net, skilfully twisted so as to retain its contents, while it lay amid the herbage, and he himself went with light and wellplanted footsteps in search of the treasure. (WD 148)

The care Roger demonstrates for flora and fauna is certainly part of his scientific interest; it is difficult, however, to demonstrate that this character trait derives from Gaskell's reading of White's Natural History.

53 [J. D. Forbes], 'Lyell on the Antiquity of Man', Edinburgh Reviem, 118 (1863), 296.

54 The London 1843 edn.

55 See the letter from Darwin to Leonard Jenyns (May-September 1842), in The Correspondence of Charles Darmin, ed. Burkhardt and Smith, vol. ii: 1837-1843 (Cambridge, 1986), 317. Darwin owned two copies of White's Natural History: they are in the Darwin Library, Cambridge University Library. 
There is one final source of information on what Gaskell might have read: the auction catalogue for the estate of her daughter, Margaret Emily ('Meta') Gaskell, who lived in the family home at Plymouth Grove until her death in $1913 .^{56}$ As Wheeler has, however, pointed out, the document is only of limited usefulness, because it includes few details about the books (particularly whether they were published before 1865, the year of Gaskell's death); also, many were sold in lots, together with other, unnamed, volumes. ${ }^{57}$ The (often abbreviated) titles in the catalogue ${ }^{58}$ which might be of relevance to Wives and Daughters include 'Owen's "Lectures on Comparative Anatomy", 59 'Cuvier's Animal Kingdom', 'Lyell's "Antiquity of Man" ', 'Dr. Brewer's "Guide to Science", , ${ }^{62}$ “"Geology," by Ansted, 2 vols.', ${ }^{63}$ 'Life of Priestley', ${ }^{64}$ and, on the theme of African exploration, " "Travels in Nubia," by J. Lewis Burckhardt'. ${ }^{65}$ There is, however, no way of discovering the editions described, or whether any of them was read by Elizabeth Gaskell.

Uglow attempts to offer biographical evidence for Gaskell's conception of Roger. The novelist visited Edinburgh for several weeks in February 1864, and stayed at the house of George Allman, the professor of zoology who married her old friend Louisa Shaen. ${ }^{66}$ Uglow discusses this visit in the context of

56 Re The late Miss M.E. Gaskell, 84 Plymouth Grove, Manchester. Catalogue of Valuable Books, including Many Old and Rare Works and First Editions by Mrs. Gaskell, Charlotte Brontë, George Eliot, Tennyson, Kipling, Thackeray, Spenser, Browning, Ecc; and about 4000 other Volumes. To be Sold By Auction, by Messrs. George H. Larmuth $\mathcal{E}$ Sons, on the Above Premises, On Monday, February 16th, 1914, and the Following Day, if Necessary. The auctioneers also issued a sale catalogue for all the contents, including the books. Copies of the inventory are in the Gaskell Collection, Manchester Central Library.

57 M. Wheeler, 'Mrs. Gaskell's Reading, and the Gaskell Sale Catalogue in Manchester Central Library', Notes and Queries, Ns 24 (1977), 25-30. The auction is described in 'The Gaskell Sale', Manchester Guardian, 18 Feb. 1914. Some of the same problems affect the analysis of evidence about what Charles Dickens might have read: see L. Litvack, 'What Books Did Dickens Buy and Read? Evidence from the Book Accounts with his Publishers', Dickensian, 94 (1998), 85-130.

58 The lot numbers attached to these titles are 37, 219, 541, 32, 58, 325, and 88.

59 R. Owen, Lectures on the Comparative Anatomy and Physiology of the Invertebrate Animals, delivered at the Royal College of Surgeons, in 1843; Lectures on the Comparative Anatomy and Physiology of the Vertebrate Animals . . . in 1844 and 1846, 2 vols. (London, 1843-6).

60 Translations of Cuvier's Le Regne Animal appeared from the late 1820s onward. It is impossible to know which edition the Gaskells owned.

61 C. Lyell, The Geological Evidences of the Antiquity of Man, with remarks on theories of the origin of species by variation (London, 1863).

62 Ebenezer Cobham Brewer, Dr. Bremer's Guide to Science.

63 David Thomas Ansted published two volumes approximating this title: Geology, introductory, descriptive and practical, 2 vols. (London, 1844), and An Elementary Course of Geology, Mineralogy, and Physical Geography (London, 1850).

64 This title might be J. Corry's Life of Foseph Priestley (Birmingham, 1804), or J. T. Rutt's Life and Correspondence of Foseph Priestley, 2 vols.(London, 1831, 1832).

65 J. L. Burckhardt, Travels in Nubia (London, 1819); a second edn. was published in 1820.

66 Gaskell penned a letter to her American friend Charles Eliot Norton from 'Dr Allman's, (The Professor of Natural History)'; see Letters, 724. The letter is dated 1 Feb. 1864. 
Edinburgh's reputation as a centre for the study of natural history, and as an institution which produced explorers and travellers who spanned the globe, including Charles Darwin, who had studied medicine there briefly-from 1825 to $1827 ;^{67}$ yet despite her claim that the character of Roger Hamley 'began to evolve in her mind' during Gaskell's visit to Scotland, the biographer fails to provide any supporting evidence. ${ }^{68}$

There are other interesting aspects to Darwin's sojourn in Edinburgh. $\mathrm{He}$ undertook his medical studies there at the time when Geoffroy's influencewith its radical implications - was growing at the institution. He got to know Robert Edmond Grant (1793-1874), who was Geoffroy's most consistent British supporter, a defender of Erasmus Darwin's Zoonomia (1794-6), and Richard Owen's political and philosophical opponent; it was Grant who encouraged Darwin's interest in natural history - particularly marine invertebrates. When Darwin switched to Cambridge, and a potential clerical career, ${ }^{69}$ he was pushed in an anti-radical direction; he entered an atmosphere where William Paley's Natural Theology (1802) treated Zoonomia as its principal target. ${ }^{70}$ By 1837 Darwin was carrying around a diverse collection of political baggage; the news from home that he received while on his Beagle voyage was full of foreboding and fears that the radicals were gaining strength. On his return, Desmond notes, he 'steered an antiradical and storm-free course suited to a gentleman drawing on a father's bank'. Indeed Desmond goes so far as to suggest that 'the interplay between his family's Whiggism, his Cambridge patronage, and the widespread fear of urban radicals provides a possible clue to his publishing delay' of the Origin of Species. ${ }^{71}$

If Wives and Daughters can serve as a vehicle for transmission of the social

67 Uglow, Elizabeth Gaskell, 560; she mentions Mungo Park, James Bruce, William Balfour Baillie, Alexander Dalrymple, William Scoresby, John Richardson, Richard Spruce, and the researchers who accompanied Sir John Franklin to the Arctic. On Darwin's time in Edinburgh see A. Desmond and J. Moore, Darmin (London, 1991), 21-30; Darwin left the institution without a degree.

68 See also Debrabant, who claims-also without significant evidence-that in Edinburgh Gaskell 'found herself in a favourable context for stimulating thoughts on matters biological': 'Birds, Bees, and Darwinian Survival Strategies', 16.

69 Desmond explains that 'the idea of ordination in the Church of England was not so odd in Darwin's case. Nor was it odd that his freethinking father packed him off to Cambridge. The Darwin-Wedgwood family typified the wealthier aspects of the provincial Whig squirearchy, not least in its practical attitude towards the social and recreational benefits of a Church career. The curacy was a safety net for second sons, preventing them from turning into wastrels on the family fortune. Charles seemed suited as a sporting naturalist gent': The Politics of Evolution, 403.

70 Erasmus Darwin's Zoonomia suggested natural processes of organic change, and included a chapter on transmutation. Paley's book, on the other hand, was an exposition of the 'argument by design'- that is, the claim that species are designed by an intelligent Creator, in the way that a watch is built and designed by a watchmaker. Paley's position was accepted because the alternative of natural evolution was inconceivable; Bowler adds that 'even Darwin had his attention focused on the problem of adaptation by his early interest in Paley's book': Charles Darmin, 18.

71 The Politics of Evolution, 403. Darwin's allowance, together with that of Emma, amounted to $£ 1,300$ per annum. 
and political implications of transformationism (in the tradition of Geoffroy and Darwin), it is largely achieved by inference, and by suggesting applications for the future. Political issues with profound consequences for the shape of English society are mentioned in the text: these include Catholic emancipation (WD 299) and the 1832 Reform Bill (WD 36). However, as Henson notes, the 'distinctive homogeneity' of Gaskell's rural communities draws on 'irresistible natural rhythms' to induce inertia. ${ }^{72}$ In the Hollingford of the late 1820 s and early 1830s, clear distinctions are drawn between Whigs and Tories: Gaskell observes that 'the old party distinction' in this fictional Knutsford 'was still a shibboleth by which men were tested as to their fitness for social intercourse, as well as on the hustings'. Yet a different dynamic exists in the city: it is there that a 'volatile nervous excitement' can be felt ${ }^{73}$ which induces Lord Cumnor to offer hospitality to any agreeable acquaintances, be they 'Whig, Tory, or Radical' (WD 386). Gaskell is careful to note which characters are associated with London, and which are not. For example, Mrs Hamley, a 'fine London lady', had married the Squire, who avoids the capital, believing that 'he had got all that was worth having out of that crowd of houses'; yet clearly his unenlightened attitudes stem partly from his refusal to recognize that 'there might still be something worth hearing and seeing in the great city' (WD 73, 74). Roger's London sojourn, after becoming Fellow of Trinity (WD 359, 398), has important consequences: it is here that he discovers he has been chosen to lead a scientific expedition. Desmond notes that in Regency London 'Geoffroyan biology meshed well with the radical understanding of nature and society', which advocated that social ills could be ameliorated through environmental manipulation, through better sanitation, welfare, housing, and health care. ${ }^{74}$ Though treatment of such issues is reserved for Gaskell's earlier 'social problem' novels, by placing Roger, whose head is 'full' of 'comparative anatomy' (WD 113) at the centre of London biological debate in the late $1820 \mathrm{~s}$, the novelist is indicating his exposure to-and subsequent influence by-transformationist ideas.

Mr Gibson's medical practice might also serve as an indicator of transformationist sympathies. His Scottish origins (WD 61) might have been introduced by Gaskell in order to indicate affiliation with radical science; Edinburgh University boasted an upsurge in the 'potent ideology' of materialistic thought in the period 1826-33, when scholars such as Grant first broached the idea of organic self-emergence, and speculated on a transmutatory relationship for all organisms. ${ }^{75}$ These implications are not followed through in Wives and Daughters, but Gaskell is careful to note that Mr Gibson's medical knowledge is not something to be shared readily: Molly reads everything in the Gibson household on which she can lay her hands, except the medical texts, which her father keeps locked away in his surgery (WD 65-6). In Hollingford $\mathrm{Mr}$

72 Henson, 'The "Condition-of-England” Debate', 36.

73 Ibid.

74 The Politics of Evolution, 107.

75 Ibid. 60,69 . 
Gibson's medical researches are encouraged: after meeting and conversing with Lord Hollingford he is inspired to send contributions to 'the more scientific of the medical journals' (WD 70). The point is significant, for in the 1820s three journals with transformationist sympathies emerged: the MedicoChirurgical Reviem (founded 1820), the London Medical and Surgical Fournal (founded 1828), and The Lancet (founded 1823): all three were organs for reform, demanding democracy and an end to privilege. The MedicoChirurgical Reviem spoke for moderate reform of educational standards, and unimpeded access to corporate power. The London Medical and Surgical Fournal was geared towards Dissenting readers, promoting an anti-Anglican but still Christianized anatomy. The Lancet, attracting massive support from radical GPs, promoted radical unions, anti-Poor Law action, suffrage, secularism, and mechanistic comparative anatomy, while savaging consultants, corporation leaders, Tory and Whig aristocrats, the Church, and Anglican universities. ${ }^{76}$ If Gaskell intends one of these as the organ for Gibson's publications, then it identifies him as a medical practitioner with inclinations towards reform. The novelist takes great pains to demonstrate how his conduct with his patients differs from that of his predecessor, Mr Hall, who was a favourite of the aristocracy (WD 69). Indeed, Mr Gibson's particular interest in the poor $(W D 71,94,365)$ might substantiate an interest in one of the key issues championed by The Lancet. ${ }^{77}$ The doctor's 'democratic' demeanour (WD 678) throughout the text is characterized by a dislike of pretence, and a reliance on rationalism, logic, and medical science to discern the true nature of individuals. Significantly, it is he who, from a scientific standpoint, explains to Squire Hamley Roger's superiority over Osborne: he attributes it to the 'material cause of a thoroughly good constitution'. Gibson, 'being a doctor', clearly intends the Squire to take this to mean physical health (WD 412), but, given the constant comparison of the brothers' achievements, Mr Gibson's observations confirm him as an accurate — even incontestable—judge of character.

The above discussion indicates that, in their various ways, Roger, Lord Hollingford, and Mr Gibson facilitate progress, greater understanding, and openness to new ideas for the inhabitants of Hollingford. The acceleration of change towards the novel's close (when its chronology extends into the Victorian period) is accentuated by references to the railways: in chapter 52 they are called 'newfangled' ( $W D$ 616), thus intimating a date about 1830; but in chapter 57 Lady Cumnor mentions the new London-to-Birmingham line, which opened in 1838. By this stage Cynthia, who had 'dreaded' Roger's 'learning' (WD 618-19) has fallen in love with Mr Henderson, and is to marry him (WD 671), thus clearing the way for an attachment between Roger and

76 See ibid. 15-16. Mr Gibson also writes 'thoughtful letters to his medical brethren in London' (WD 557).

77 Desmond notes how hostility towards the Poor Law Amendment Act of 1834 brought together provincial moderates and metropolitan radicals, in their opposition to placing the sick poor in workhouses; see The Politics of Evolution, 126. 
Molly. Roger, 'the scientific Mr. Hamley', who has become famous for his travels (WD 660, 662), returns briefly to Hollingford, resolving never again to live at Hamley Hall, which for him is the emblem of a past life. Yet once again he serves as the catalyst for change, by asking Molly to act as conciliator between Aimée and Squire Hamley (WD 675, 686). The final accommodation that is reached between these two characters, who become 'friends', is representative of a compact that is reached between the English and French more generally after the rivalries that dominated the first three decades of the nineteenth century. The reconciliation was particularly important in the field of science, which became the 'cement' for the bonds of society. ${ }^{78}$

While a consideration of science in the text emphasizes the potential for change in political and social conditions at home in England, experiences abroad also function as an important commentary on the role of science in imperial endeavour. Mary Louise Pratt has argued that, from the mideighteenth century onward, science 'came to articulate Europe's contacts with the imperial frontier', and was part and parcel of the impulse to master the globe. She characterizes natural history as a structure of knowledge within a 'new planetary consciousness' and totalizing conception of the world which was a direct result of colonial expansion. She explains:

One by one the planet's life forms were ... drawn out of the tangled threads of their life surroundings and rewoven into European-based patterns of global unity and order. The (lettered, male, European) eye that held the system could familiarize ('naturalize') new sites/sights immediately upon contact, by incorporating them into the language of the system. ${ }^{79}$

Figures such as Geoffroy (who participated in the French imperial project by visiting — and indeed plundering - the treasures of Egypt), Cuvier, Lamarck, and Darwin were all engaged in a systematizing endeavour to incorporate, learn from, and then displace rival knowledge systems in what Pratt calls the 'contact zones' - that is, those spaces where disparate cultures 'meet, clash and grapple with each other ... in highly asymmetrical relations of dominance and subordination' ${ }^{80}$ Gaskell's dispatch of Roger to Abyssinia is symptomatic of European penetration into other lands, through the supposedly 'objective' means of scientific discovery.

The novelist's presentation of Roger's African travels belies an ignoranceor at least a reticence-about the colonial space he enters. ${ }^{81}$ On one level it is a convenient plot device, designed to exclude him while various secrets in the novel are revealed, and their consequences allowed to emerge: Preston's

78 Knight, The Age of Science, 15.

79 M. L. Pratt, Imperial Eyes: Travel Writing and Transculturation (London, 1992), 31.

80 Ibid. 4.

81 Interestingly, the novelist seems to display greater interest in imperial—and militaryexploits in India: see J. M. Fenwick, 'Mothers of Empire in Elizabeth Gaskell's Cranford', English Studies in Canada, 23 (1997), 409-26. 
encounters with Cynthia (who is engaged to Roger), and Osborne's marriage to Aimée. Gaskell prepares for Roger's departure by noting, in chapter 31, that he 'looked forward to an active life', and had put away sufficient funds 'for the ready furtherance of any project he might see fit to undertake' (WD 391). In chapter 32 Roger reveals that Lord Hollingford 'knows my great wish for employment, and has heard of something which he considers suitable' (WD 397 ), which is 'to make a scientific voyage' to 'distant lands' (WD 405) —a designation which was first rendered in the manuscript as 'the tropicals' ${ }^{82}$ In chapter 33, which opens a monthly number, Roger is characterized by Lord Hollingford as the perfect representative of imperial endeavour:

Roger had deep interest in the subject; much acquired knowledge, and at the same time, great natural powers of comparison, and classification of facts; he had shown himself to be an observer of a fine and accurate kind; he was of the right age, in the very prime of health and strength, and unshackled by any family ties. (WD 410)

This characterization, like the one cited above concerning Roger's talents and tastes, is again reminiscent of Smiles's Self-Help.

Roger is bound for a 'hot climate' (WD 414), and by the time he departs in chapter 34 he has been schooled in the binary logic of imperialism, allowing him to recognize and maintain those supposedly unassailable ideological distinctions between races which are central to both scientific exploration and the imperial project. The 'fauna' (WD 405) which he collects on his expedition are never explicitly mentioned, but only referred to generally, as by Cynthia, who tells Molly that Roger's letter contains 'a great deal about birds and beasts' (WD 527). While he is away the discussion among his family and friends centres largely on racial difference; their rather facile pronouncements on this topic serve to establish and promote a relation of dominance of the elite over the subaltern, and so justifies the imperial enterprise. When Mr Gibson mentions Roger's 'future wife' Cynthia to Squire Hamley, the father exclaims: 'Roger's "future wife!"-He'll be wiser by the time he comes home. Two years among the black folk will have put more sense in him.' The 'democratic' Mr Gibson (WD 678) replies:

Possible, but not probable, I should say. . . Black folk are not remarkable for their powers of reasoning, I believe, so that they have not much chance of altering his opinion by argument, even if they understood each other's language; and certainly if he shares my taste, their peculiarity of complexion will only make him appreciate white skins the more.

Despite the interest the doctor claims to have in Roger's expedition, his pronouncements on it amount to nothing more than ill-informed hearsay and stereotyping. When Roger returns, Gibson, in an exchange with Molly, ventures an opinion on how the young man has developed during his time abroad: 
'If a young man of twenty-four ever does take to growing taller, I should say that he was taller. As it is, I suppose it's only that he looks broader, stronger-more muscular.'

'Oh! is he changed?' asked Molly, a little disturbed by this account.

'No, not changed; and yet not the same. He's as brown as a berry for one thing; caught a little of the Negro tinge, and a beard as fine and sweeping as my bay-mare's tail.'

'A beard! but go on, Papa. Does he talk as he used to do? I should know his voice amongst ten thousand.'

'I didn't catch any Hottentot twang, if that's what you mean. ${ }^{83}$ Nor did he say, "Caesar and Pompey berry much alike, especially Pompey," which is the only specimen of Negro language I can remember just at this moment.' (WD 644)

Mr Gibson's observations reduce questions of race to what Uglow generously terms 'patronizing stereotypes and music-hall jokes'. ${ }^{84}$ His wife's remarks are less insightful, but more sensational: she characterizes Africa as an 'unhealthy, 'savage', and 'cannibal country' (WD 575), thus enunciating the hierarchized relationship between Europe and its perceived 'Others'.

It is interesting to note that some of these perceptions of Africa are perpetuated in the $1999 \mathrm{BBC}$ adaptation of Wives and Daughters. ${ }^{85}$ Andrew Davies's screenplay visualizes Roger's African sojourn by depicting him as the sole European on his expedition, trekking across bare, open plains, accompanied by camels and porters. In the voice-over rehearsal of letters to Cynthia, Roger (played by Anthony Howell; Figure 2) speaks of his situation in a 'country' which is a 'constant hazard and adventure'; he notes how he is acquiring the language, and learning to survive in 'this wonderful land'. In subsequent brief scenes, he is carried on a stretcher after surviving a fall, acknowledging that Cynthia's love sustains him in that 'savage' landscape. After his return, at a dinner at the Towers in his honour, Roger is asked by one of the women present if the natives really do eat each other; he jokingly replies, 'Only rarely. The flesh of the European is considered the real delicacyespecially the females.' Such is the general response to Africa on the part of the Europeans; Molly, however, is different. The filmmakers endow her with genuine curiosity about Roger's travels: she not only examines under a microscope one of the specimens Roger has dispatched, but also, in his absence, she traces his movements with a red ribbon on a map of Abyssinia. This interest is rewarded in the drama in the final scene, which features Molly and Roger (now married), on an African plain, walking hand in hand into the distance.

83 The Hottentot language is spoken by the Nama people, who formerly inhabited the Cape region; it is characterized by its use of click consonants.

84 Uglow, Elizabeth Gaskell, 586.

85 N. Renton, Wives and Daughters (BBC, 1999). Though now available on video, the drama was originally broadcast on BBC1 in four weekly parts, on 28 November, and 5, 12, and 19 December. 


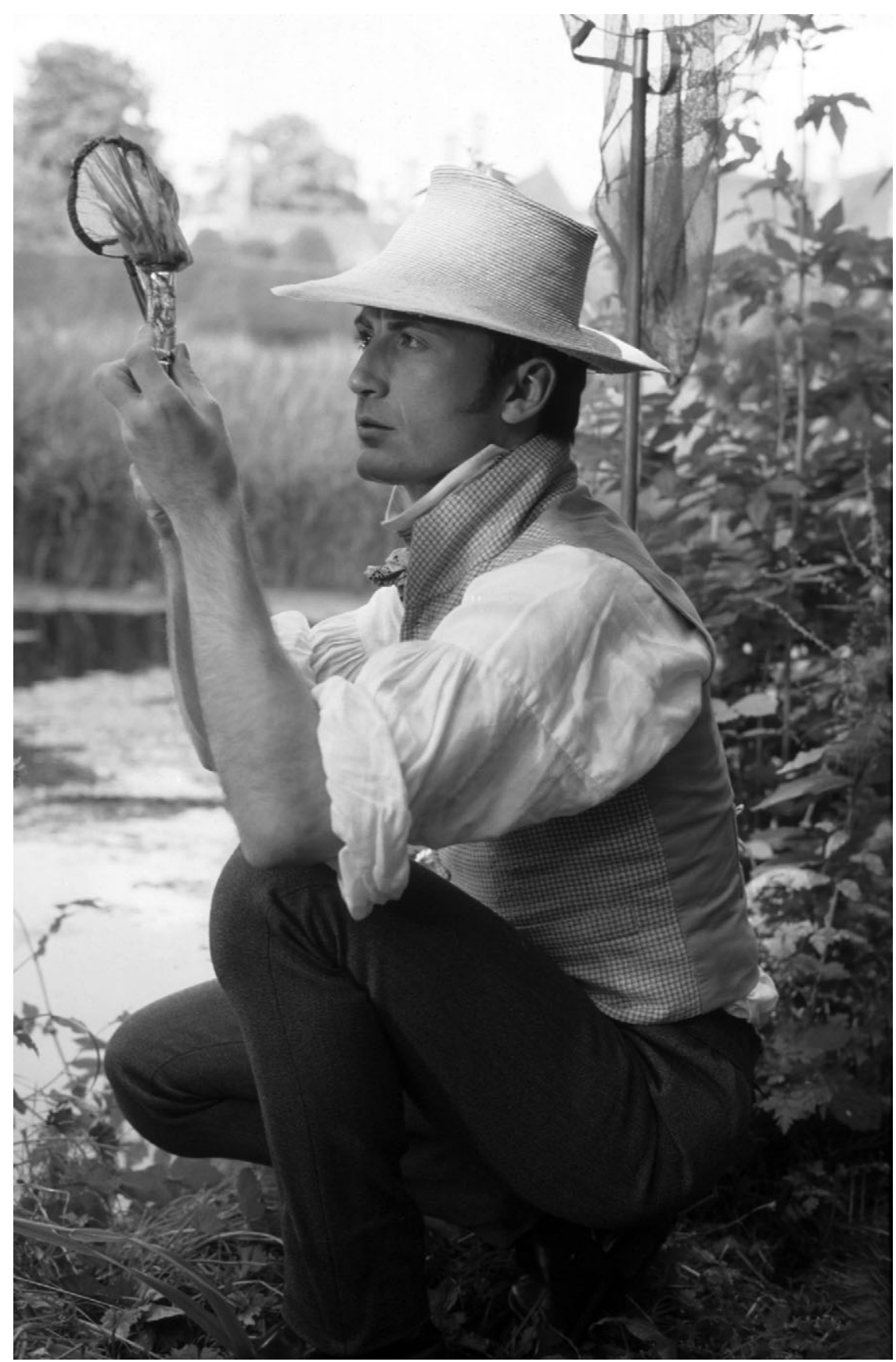

Figure 2. Actor Anthony Howell, who played Roger Hamley in the 1999 BBC adaptation of Wives and Daughters. Reproduced by kind permission of the BBC Picture Library. 


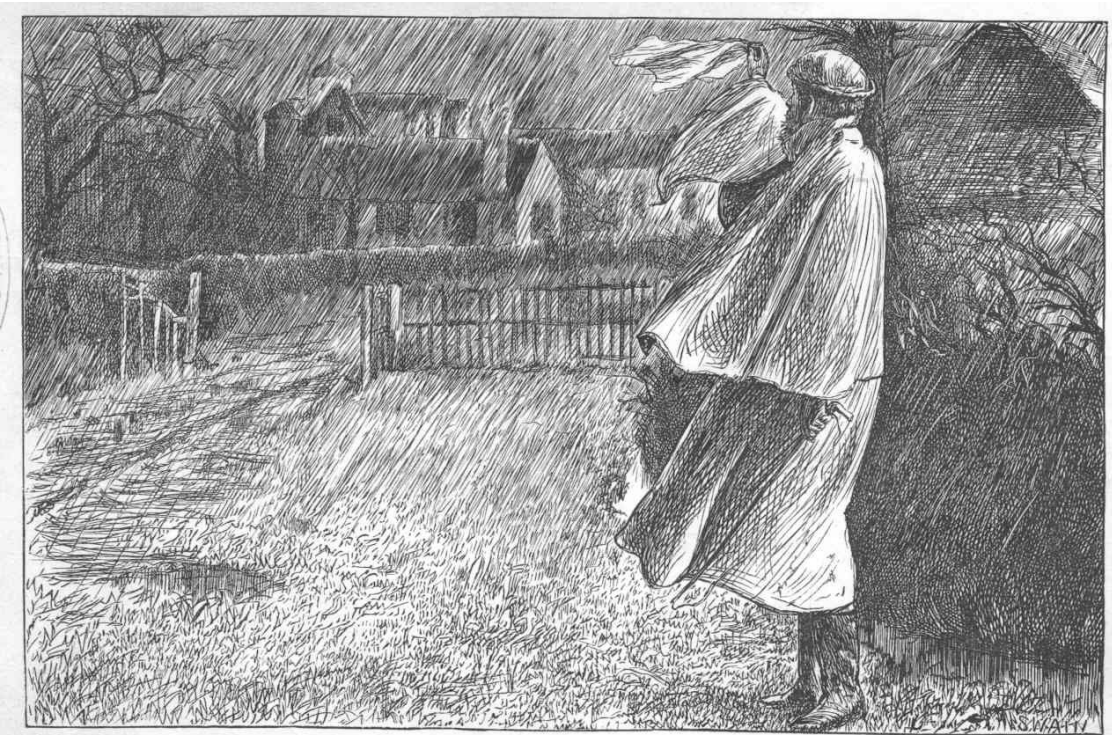

Figure 3. George Du Maurier, 'The Last Turning', an illustration for Wives and Daughters; it depicts Roger's last look at his home before departing on his second scientific expedition.

In Gaskell's novel, Molly of course never travels to Africa. In chapter 55 Roger returns from his first voyage 'a strong grown-up man' (WD 651), and 'famous traveller', whose report generates great interest at a meeting of the Geographical Society (WD 498). ${ }^{86}$ Lord Hollingford confirms that the naturalist is to have a 'European reputation' (WD 676) - but not before he travels again to the Cape (WD 687; Figure 3), without speaking directly to Molly. Only on his return, he thinks to himself, could he 'gain the woman who was to him the one who excelled all' (WD 693). Had Gaskell lived to complete the novel, Roger would, according to Frederick Greenwood, editor of the Cornhill Magazine, have married Molly, and would have become 'professor at some great scientific institution', winning his way 'handsomely' in the world (WD 706, 707). ${ }^{87}$ Interestingly, A. W. Ward suggests that at the time of the novelist's death she was trying to discover, 'through a scientific friend', the kind of public acknowledgement or appointment which Roger could have expected; Sharps believes that this friend may have been Charles Darwin. ${ }^{88}$

86 The Geographical Society (later the Royal Geographical Society) was founded in 1830; it strongly supported British expansion into Africa — especially during the presidency of Roderick Murchison (1843-71).

87 Gaskell died of heart failure on 12 Nov. 1865; Greenwood's concluding remarks appeared in January 1866. The editor discovered something of the novelist's intentions from one of her daughters, probably Meta Gaskell. See Sharps, Mrs. Gaskell's Observation and Invention, 469-70.

88 A. W. Ward, introduction to Wives and Daughters, Knutsford edn., vol. viii (London, 1906), p. xvii. For Sharps's comments see Mrs. Gaskell's Observation and Invention, 519. 


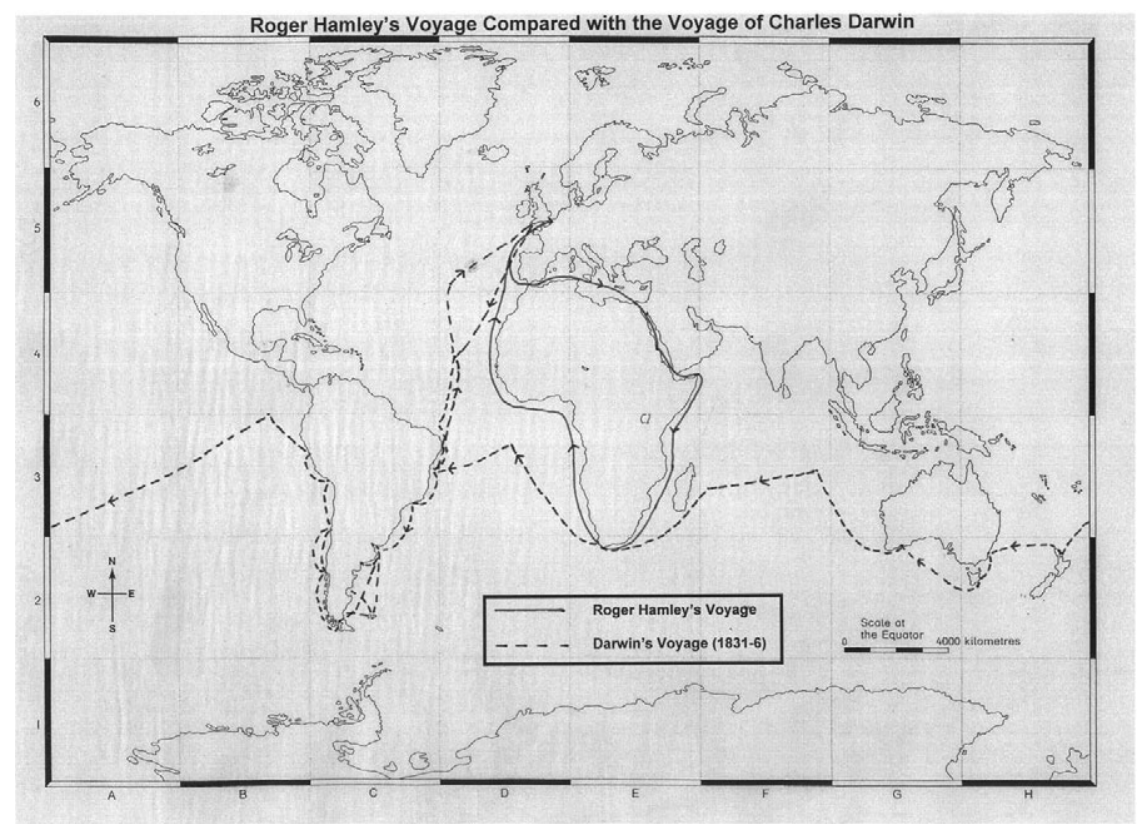

Figure 4. Roger Hamley's voyage round Africa, compared with Charles Darwin's voyage on the Beagle. Roger stops in Paris, before embarking for Egypt from Le Havre. He then travels to Abyssinia, and on to the Cape, before returning to England along the west coast of the continent.

It is certainly striking - given Gaskell's competent knowledge of the key scientific debates circulating at the time the novel is set-that she spends so little time sketching in the details of Roger's African explorations. Whereas Darwin, in his voyage on the Beagle, ventured westward, to South America, the Galapagos Islands, Tahiti, New Zealand, Australia, and the Cape (Figure 4), Roger journeys to Paris 'to have interviews with some of the scientific men there', before embarking at Le Havre (WD 414) for Egypt, and Abyssinia, where he spends most of his time, and where, Molly reflects, there was 'no society, no gaiety, no new books to write about', and 'no gossip' (WD 460). ${ }^{89}$ He then journeys to 'Arracuoba', described as 'a district in Africa, hitherto unvisited by any intelligent European traveller' (WD 498) ${ }^{90}$ He finally reaches the Cape, and then returns to England around the western side of the continent.

From the mid-1850s the exploration of Africa was beginning to invade the Victorian imagination, aided by such works as David Livingstone's Missionary Travels (1857), which sold 70,000 copies, made the author wealthy and famous,

89 Cynthia's approximation of Roger's location is 'Huon', which seems not to correspond to an actual place ( $W D 459)$; in the BBC drama this is rendered as 'Harrar', which does.

90 The name 'Arracuoba' is Gaskell's invention. 
and transformed him into a national hero; Richard Burton's Lake Regions of Central Africa: A Picture of Exploration (1860); and John Hanning Speke's Discovery of the Sources of the Nile (1863). The periodicals were deeply interested in travel and exploration. Indeed in those which Gaskell is known to have read the extent of coverage is considerable. The Westminster featured, from 1854, a separate review section on 'History, Biography, Voyages and Travels', whose authors included James Anthony Froude (1818-94) and George Eliot. ${ }^{91}$ Harriet Martineau (1802-76) also contributed reviews, and an extended piece on 'Travel During the Last Half Century', which considers the intellectual, political, and economic gains made in acquiring knowledge of a host of territories, including Canada, Lapland, Siberia, Japan, China, Australia, Tasmania, New Zealand, Borneo, and Antarctica. The essay also treats 'barbaric Abyssinia' in the context of Richard Burton's First Footsteps in East Africa; or, An Exploration of Harar (1856); Martineau appeals to the manufacturing classes to be thankful to Burton (1821-90) for 'opening up a prospect of cotton supply', and more generally, for 'laying open' to European sensibilities the 'recesses' and 'mysteries' of 'Mahommedan sanctity'. ${ }^{92}$ Such comments illustrate Richards's thesis that an interesting feature of colonial expansion was the need to classify and place in a vast 'imperial archive' all that was observed and collected. ${ }^{93}$ This classificatory obsession was also observable in other reviews, such as Charles T. Beke's 'The Basin of the Upper Nile and its Inhabitants', which considered, among other texts, Speke's Journal of the Discovery of the Sources of the Nile. ${ }^{94}$

Speke (1827-64) had an arrangement with Blackmood's Edinburgh Magazine (which Gaskell read) in the years 1859-60, for publishing the text of his African journals. In his account of the exploration of Lake Tanganyika (in the company of Richard Burton) he concentrates on cartography, owing to his position as surveyor, responsible for 'mapping, entering topographical remarks, and shooting for the pot'. ${ }^{95}$ In subsequent submissions he provided

91 See e.g. Westminster Reviem, 61 (1854), 282-301, for reviews by Froude, and Westminster Reviem, 66 (1856), 553-66, for reviews by Eliot.

92 [H. Martineau], 'Travel During the Last Half Century', Westminster Review, 70 (1858), 452-3.

93 T. Richards, The Imperial Archive: Knomledge and the Fantasy of Empire (London, 1993) 3; he observes: 'From all over the globe the British collected information about the countries they were adding to their map. They surveyed and they mapped. They took censuses, produced statistics. They made vast lists of birds. Then they shoved the data they had collected into a shifting series of classifications. In fact they often could do little other than collect and collate information, for any exact civil control, of the kind possible in England, was out of the question. The Empire was too far away, and bureaucrats of Empire had to be content to shuffle papers. This paper shuffling, however, proved to have great influence. It required keeping track, and keeping track of keeping track. It required some kind of archive for it all.'

94 Westminster Reviem, 81 (1864), 307-48. Charles Tilstone Beke (1800-74) mapped 70,000 square miles of Ethiopia in 1840-3; he also determined the approximate course of the Blue Nile, and compiled vocabularies of fourteen languages and dialects.

95 [J. H. Speke], 'Journal of a Cruise on the Tanganyika Lake, Central Africa', Blackwood's Edinburgh Magazine, 86 (1859), 339. 
accounts of his expedition to Somaliland in $1854,{ }^{96}$ and of his discovery (unaccompanied by Burton) of Lake Victoria in 1858. In the latter he emphasized the potential for trade and agriculture in the region, expressing a 'fervent hope' that 'England especially' will 'not neglect this land of promise'; Speke highlighted the role of missionaries as 'promoters' of the discovery, noting that 'they have been . . . doing their utmost, with simple sincerity, to Christianise this negro land, and promote a civilised and happy state of existence for those benighted beings' ${ }^{97}$ Speke's report also had a scientific element: in its conclusion it featured a study of freshwater molluscs by Samuel P. Woodward (1821-65, a geologist at the British Museum), ${ }^{98}$ who developed his ideas from the specimens that Speke brought back. When Blackmood's reviewed Discovery of the Sources of the Nile, it described Speke as a 'brilliant writer' and 'indefatigable explorer' endowed with 'intuitive genius'; indeed it transformed him into a superhuman figure:

As the fiercest wild beasts are said to be appalled by the eye that shows no impression either of ride or wrath, so the sanguinary potentates among whom our explorer went, demanding nothing but a clear path to the head of the Nile, but determined to get that, seem to have restrained in their amazement the natural impulses of their ferocity. ${ }^{99}$

The explorer's death in 1864 prompted an obituary in which he was hailed as a 'tried soldier', 'bold explorer', and 'sagacious discoverer' for whom 'immortality' was certain. ${ }^{100}$

Richard Burton's arrangement with Blackmood's paralleled Speke's. In a three-part travelogue entitled 'Zanzibar; and Two Months in East Africa', clearly conceived as a kind of non-fictional quest romance, Burton, the heroexplorer, characterizes the thrill of the endeavour:

Of the gladdest moments, methinks, in human life, is the departing upon a distant journey into unknown lands. Shaking off with one effort the fetters of Habit-the leaden weight of Routine - the cloak of carking Care, and the slavery of home-man feels once more happy. The blood flows with the fast circulation of youth, excitement gives new vigour to the muscles, and a sense of sudden freedom adds an inch to the stature. Afresh dawns the morn of life, again the bright world is beautiful to the eye, and the glorious face of nature gladdens the soul. A journey, in fact, appeals to Imagination, to Memory, to Home - the sister graces of our moral being. ${ }^{101}$

96 'Captain Speke's Adventures in Somali Land [sic]', Blackwood's Edinburgh Magazine, 87 (1860), 561-80, 674-93; 88 (1860), 22-36.

97 'Captain J. H. Speke's Discovery of the Victoria Nyanza Lake, the Supposed Source of the Nile. From His Journal', Blackwood's Edinburgh Magazine, 86 (1859), 578.

98 Woodward was the author of $A$ Manual of the Mollusca, in three parts $(1851,1853$, and 1856).

99 'Captain Speke's Journal', Blackwood's Edinburgh Magazine, 95 (1864), 2, 17-18.

100 'The Death of Speke', Blackmood's Edinburgh Magazine, 96 (1864), 514, 516. For a biography see A. Maitland, Speke (London, 1971).

101 [R. F. Burton], 'Zanzibar; and Two Months in East Africa', Blackmood's Edinburgh Magazine, 83 (1858), 200. 
He provides a catalogue of skills which the African traveller must possesspartly in order to satisfy the demands of a Victorian readership:

The African traveller, in this section of the nineteenth century, is an animal overworked. Formerly the reading public was satisfied with dry details of mere discoverywas delighted with a few latitudes and longitudes. Of late, in this, as in other pursuits, the standard has been raised. Whilst marching so many miles per diem, and watching a certain number of hours per noctem, the traveller, who is in fact his own general, adjutant, quarter-master, and executive, is expected to survey and observe, to record meteorology, hygrometry, and hypsometry - to shoot and stuff birds and beasts, to collect geological specimens, to gather political and commercial information, to advance the infant study ethnology, to keep accounts, to sketch, to indite a copious legible journal, to collect grammars and vocabularies, and frequently to forward long reports which shall prevent the Royal Geographical Society napping through evening meetings. ${ }^{102}$

The hero/author, according to Burton, must trek through enchanted, 'bedevilled' lands towards specific goals, ${ }^{103}$ which for him included, in the course of his career, exposure of the 'secrets' or 'treasures' hidden in Medina and Mecca, or in the forbidden East African city of Harar. ${ }^{104}$ Burton's travels illustrate an important imperial necessity: that the collection, classification and adaptation of knowledge, undertaken in the field, are essential to the establishment of authority. The information and specimens collected by the explorers Burton and Speke-and fictionally by Roger Hamley-were regarded as something to be utilized, rather than simply placed in an archive or museum. Also, their classifications of race-flawed and limited though these were- established a hierarchy, which was inextricably linked to the pursuit of political power.

The impressions of Burton and Speke, gleaned either from periodical publications or from their travelogues (which are in the Portico's collection) might, therefore, have contributed to Gaskell's conception of Roger's sojourn in Abyssinia. The territory might also have appealed because it extended the British-French rivalry that she had already considered through Roger's affinity for Geoffroy: in the 1830s the French sent distinguished geographical and scientific missions to Abyssinia; there they encountered English explorers and missionaries. ${ }^{105}$ Their exploitation of local tribal politics created two

102 [Burton], 'Zanzibar', 580.

103 See P. Brantlinger, Rule of Darkness: British Literature and Imperialism, 1830-1914 (Ithaca, NY, 1988), 180.

104 See Burton's Personal Narrative of a Pilgrimage to Al-Medinah and Meccah, 3 vols. (London, 1855-6), and his First Footsteps in East Africa; or, An Exploration of Harar (London, 1856); the explorer understood the Persian, Afghan, Hindustani, and Arabic languages, and undertook these journeys in disguise, because the sites he visited were closed to Europeans. See M. S. Lovell, $A$ Rage to Live: A Biography of Richard and Isabel Burton (London, 1998).

105 One of the most prominent English missionaries and explorers in Abyssinia during this period was Lewis Krapf, who represented the Church Missionary Society, and on his return published Travels, Researches, and Missionary Labours, during an Eighteen Years' Residence in Eastern Africa (1843). 
antagonistic groups: one sympathetic to British Protestantism, the other approving of French Catholicism. Yet another reason for Gaskell's interest in Abyssinia might be the perceived risk to British travellers, occasioned by the imprisonment of a group of men-including a British consul-by King Theodorus II in 1864. Reports of the incident, and the negotiations to free the prisoners, appeared in the press while Gaskell was writing about Roger's African sojourn (Figure 5). ${ }^{106}$

Gaskell's inclusion of so few details emphasizes the point that colonies were imaginative and discursive constructs before they became materially explored - and exploited - outposts of empire. This point is clearly made by Martineau in her Westminster Reviem article: she compares Richard Hakluyt's account of early voyages $(1599)^{107}$ with information on geography gleaned from Charles Knight's English Cyclopedia (1855), to reveal that whereas in former times 'the delight in voyages and travels was chiefly as a luxury of the imagination', by the mid-nineteenth century, exploration narratives-which have revealed so much about the world in minute detail-have produced an impression that 'our remaining wants will assuredly be supplied'. The economic rationale for imperial endeavour is emphasized in the article's conclusion:

More demands, new products; more wants, new markets; and, latterly, a fresh supply of gold in the nick of time; these results of exploratory travel show a prodigious modification of the popular life of our country, without taking into the account the comforts and conveniences which fall to every man's share in the distribution of foreign commodities. His dwelling, furniture, clothing, food, locomotion, pleasures, are all more or less made up of the results of geographical discovery; and his thoughts and feelings must necessarily be so too. ${ }^{108}$

Gaskell is more interested in the imaginative impact of exploration, and perhaps in what Martineau identifies as the particular contribution of science in the minds of the Victorians: to raise 'human and national self-respect . . by

106 Some of the prisoners were held until 1868. Theodorus, a Coptic Christian, had asked the British to supply him with munitions and military advisers for his campaigns against his Muslim neighbours. When his request went unheeded, he kidnapped the consul, Captain Charles Cameron, and several civilians. A relief expedition, led by British forces in India, under the command of Sir Robert Napier, was dispatched in late 1867. The Abyssinians were finally defeated at Magdala in April 1868; Theodorus committed suicide with a pistol given to him by Queen Victoria. One account of those kidnapped appeared in the year of Gaskell's death, C. T. Beke's British Captives in Abyssinia (London, 1865). Several others appeared in subsequent years: H. Dufton, Narrative of a Fourney through Abyssinia in 1862-3; with an Appendix on the Abyssinian Captives' Question (London, 1867); H. Blanc, Narrative of Captivity in Abyssinia; with some account of the late Emperor Theodore, his Country, and People (London, 1868); J. C. Hotten (ed.), Abyssinia and its People; or, Life in the Land of Prester Fohn (London, 1868); and H. M. Hozier, The British Expedition to Abyssinia (1869). For an account of the relief effort see D. Bates, The Abyssinian Difficulty: The Emperor Theodorus and the Magdala Campaign, 1867-68 (Oxford, 1979).

107 The Principal Navigations, Voyages, Traffics, and Discoveries of the English Nation, 3 vols. (London, 1598-1600).

108 [Martineau], 'Travel During the Last Half Century', 429, 464. 


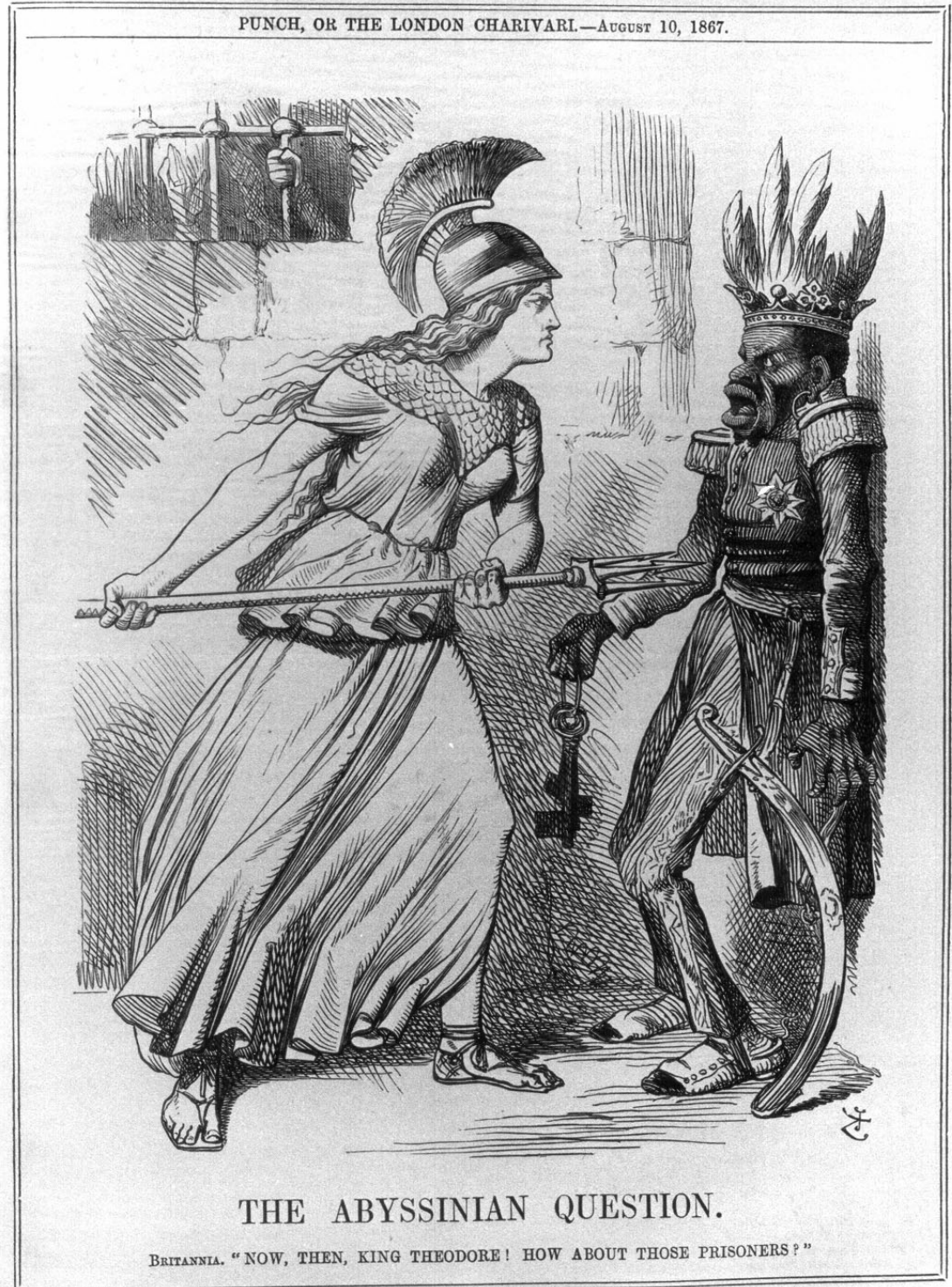

Figure 5. 'The Abyssinian Question', Punch, 10 August 1867. The illustration depicts Britannia, in a menacing pose, demanding that King Theodore should release his European prisoners. The issue was a point of discussion in the British press throughout the period of Gaskell's composition of Wives and Daughters. 
the noble spirit shown in the whole process of research'. ${ }^{109}$ Thus Mr Gibson's comment about the 'Hottentot twang' quoted above indicates not only the lack of precision with which he describes Roger's African experiences, but, more importantly, that in a sense it is of little consequence to discern precisely where he went - only that his aims were meritorious, that he did not 'go native' or succumb to miscegenation, and that he brought back a sufficient quantity of specimens to establish the Crichton Museum. Uglow attempts to excuse Gaskell's reticence by observing that, while she is 'aware that the society she describes is founded upon exploitation and empire', she chooses to 'depict a world seen through the eyes of characters whose horizons are national or local'. ${ }^{110}$ Yet the brief pronouncements about Africa in Wives and Daughters, and the fact that the novel was published at the time of enhanced African exploration, reveals a good deal about the myth of the 'Dark Continent' - an image constructed out of political and economic pressures, but also one which maintained a 'keen curiosity' in the mind of the Victorian reader. ${ }^{111}$ The emphasis placed on tribal savagery, as in Mrs Gibson's comments on cannibalism-an important theme in mid-nineteenth-century British writing about Africa ${ }^{112}$ - had the effect of draping this anti-space of European reality in a pall of darkness. Roger, with his industrialized weapons, means of communication, and transportation, represented a brand of science that served as a ruling discourse. The Africans are powerless and voiceless, but so, in some sense, is Roger, who says almost nothing about his African experiences, except that his plan was to 'cast round Africa on the eastern side until he reached the Cape; and thence to make what further journey seemed to him best in pursuit of his scientific objects' (WD 643).

While Gaskell believed that in writing Wives and Daughters she had to map out with great care the scientific debates raging in England in the 1820s and 1830 s, she was not impelled to do so for nineteenth-century colonial advancement. The way in which she leaves the African situation at the end of the novel materially affects what the continent actually becomes for herself and for her readers. The few details provided confirm that, in order for Roger to succeed and achieve his global reputation, Africa had to be presented as an appropriate site for scientific classification, mercantile enterprise, and missionary exploitation, thus depriving the indigenous inhabitants of modes of expression or adequate means of representation. In executing the plan for her 'Everyday Story' Gaskell demonstrated, at the very least, a tacit complicity

109 Ibid. 438.

110 Uglow, Elizabeth Gaskell, 586.

111 [Martineau], 'Travel During the Last Half Century', 443. See also Brantlinger, Rule of Darkness, 73-97, where he explains that the myth of the 'Dark Continent' developed during the transition from the campaign against slavery in the early part of the 19th century to the 'scramble for Africa' at its close. The term also, of course, emerges out of a psychology of blaming the victim, through which Europeans projected onto Africans their own darkest impulses.

112 Ibid. 177-9. 
with the imperial project, and so did not think it necessary or appropriate to contradict or adjust prevailing metropolitan sentiments. She also sustained the receding luxury of imagining this continent - an entirely apposite strategy for this most gifted and diligent Victorian novelist.

The Queen's University of Belfast 